\title{
Osteobiography: The History of the Body as Real Bottom-Line History
}

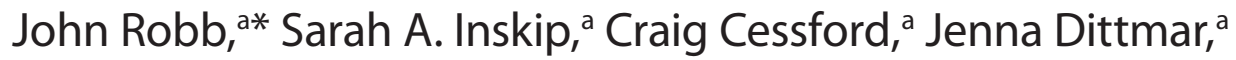 \\ Toomas Kivisild, ${ }^{\mathrm{b}}$ Piers D. Mitchell, ${ }^{\mathrm{a}}$ Bram Mulder, ${ }^{\mathrm{a}}$ Tamsin C. O'Connell, ${ }^{\mathrm{a}}$ \\ Mary E. Price, ${ }^{a}$ Alice Rose, ${ }^{a}$ and Christiana Scheib ${ }^{c}$ \\ ${ }^{a}$ Department of Archaeology, University of Cambridge, Cambridge CB2 3DZ, UK \\ ${ }^{\mathrm{b}}$ Katholieke Universiteit Leuven, Belgium \\ ${ }^{\mathrm{c}}$ Estonian Bioscience Centre, Tartu, Estonia \\ ${ }^{\star}$ Correspondence to: John Robb, Department of Archaeology, University of Cambridge, Downing Street, \\ Cambridge CB2 3DZ, UK \\ e-mail: jer39@cam.ac.uk
}

ABSTRACT What is osteobiography good for? The last generation of archaeologists fought to overcome the traditional assumption that archaeology is merely ancillary to history, a substitute to be used when written sources are defective; it is now widely acknowledged that material histories and textual histories tell equally valid and complementary stories about the past. Yet the traditional assumption hangs on implicitly in biography: osteobiography is used to fill the gaps in the textual record rather than as a primary source in its own right. In this article we compare the textual biographies and material biographies of two thirteenth-century townsfolk from medieval EnglandRobert Curteis, attested in legal records, and "Feature 958," excavated archaeologically and studied osteobiographically. As the former shows, textual biographies of ordinary people mostly reveal a few traces of financial or legal transactions. Interpreting these traces, in fact, implicitly presumes a history of the body. Osteobiography reveals a different kind of history, the history of the body as a locus of appearance and social identity, work, health and experience. For all but a few textually rich individuals, osteobiography provides a fuller and more human biography. Moreover, textual visibility is deeply biased by class and gender; osteobiography offers particular promise for Marxist and feminist understandings of the past.

Keywords: medieval; experience; osteobiography; ordinary people; biography

¿Para qué sirve la osteobiografía? La última generación de arqueólogos luchó para superar la suposición tradicional de que la arqueología es meramente (accesoria) a la historia, una sustituta que se puede utilizar cuando las fuentes escritas son deficientes. Ahora es ampliamente reconocido que las historias materiales y las historias textuales igualmente válido y complementario del pasado. Sin embargo, la suposición tradicional continúa implícitamente en la biografía: se utiliza la osteobiografía para llenar los vacíos en el historial textual en vez de utilizarla como fuente primaria por derecho propio. En esta investigación comparamos las biografías textuales y biografías materiales de dos ciudadanos de la Inglaterra medieval del siglo XIII-Robert Cuteis, documentado en registros legales, y "Feature 958", excavada arqueologicamente y examinada osteobiograficamente. Como demuestra la primera, biografías textuales de la gente común sobre todo revelan algunos rastros de transacciones financieras o legales. La interpretación de estos rastros de hecho presume implícitamente una historia del cuerpo. La osteobiografía revela una clase de historia distinta, la historia del cuerpo como un sitio que contiene información sobre apariencia e identidad social, trabajo, salud y experiencia. Para todos aparte de algunos 
pocos individuos que tienen una historia textual abundante, la osteobiografía provee una biografía más amplia y más humana. Además, la visibilidad textual está profundamente sesgada por clase y por género; la osteobiografía ofrece un potencial especial para los entendimientos marxistas y feministas del pasado.

Keywords: medieval; experienca; osteobiographía; gente común; biographía

\section{Biography with and without Texts}

Years ago, one of the classic texts of medieval history was Eileen Power's (1924) book Medieval People. It featured biographies of six medieval men and women. A tradition followed of using the biographies of "typical" people as an entrée into medieval society (e.g., Bennett 1955). Today, biographies of medieval people still form a staple of popular history. The core of these works was upper-class aristocrats, public men, and merchants, but they made an effort, usually trying to include a token woman and a token poor person. The woman was usually based on some fortuitously well documented gentlewoman such as Margery Paston or an exceptional case such as Margery Kempe; the poor person may have been a fictionalized pastiche such as Power's Frankish peasant "Bodo." Later microhistories (Davis 1984; Ginzburg 1992; Le Roy Ladurie 1978) expanded the genre, but were possible only when they hit a lucky trove of exceptionally documented material in court or inquisition records. This tradition continues; a recent compilation of medieval biographies (Bates et al. 2006) contains only one subject who is not an aristocrat, a high-ranking religious figure, or a literary figure. The one exception is based not upon textual but upon archaeological and osteological data (Fleming 2006).

Even with texts, sources reveal different things in different abundance. Chaucer and Shakespeare, the outstanding literary figures of their times, were wellknown individuals in public life, and each left over a hundred life records. Yet virtually all of their life records tell about their business transactions; we know far more of their minor property investments than of whether each really loved his wife or not. As any genealogist will tell you, this bias is true even for surprisingly recent periods. For ordinary people, particularly before parish records began in the sixteenth century and national censuses began in the nineteenth century, it is rare to have even a few life records, and a "biography" almost always consists of just a few incidental transactions and perhaps a will (cf. Fleming 2009). Such minimal documents form the tough and lasting enamel crowns of the textual record, remaining when the letters, diaries, and conversations, like fragile but informative pelvic bones, vanish in the erosion of time. Before the last couple of centuries, no textual record at all attests the very existence of the vast bulk of humanity (Fig. 1). This destruction of information filters our historical vision, making an uncritical textual history the preferential history of the rich and noteworthy. If we want to write a genuine "people's history" (Zinn 1980), a history of submerged people and their struggles, we need material evidence, above all the evidence of their own bodies.

What role can osteobiography play in balancing this situation? The answer hinges upon the relationship of texts and material remains. Traditionally, history has been based upon textual records; material remains have been regarded as ancillary, typically as a supplementary source. In fields such as Classical, historical, and early medieval archaeology, the last generation fought to establish archaeology as an equal, complementary source to textual records. Biography, however, is among the last holdouts. We still retain the idea that a biography must deal with a named individual and contain specific historical facts and dates. Skeletal studies are commonly thought of as providing generic background and color rather than detailed individual stories. This perception partly derives from our idea that imagining an individual requires a name, a face, and a backstory (Robb 2009). Indeed, with

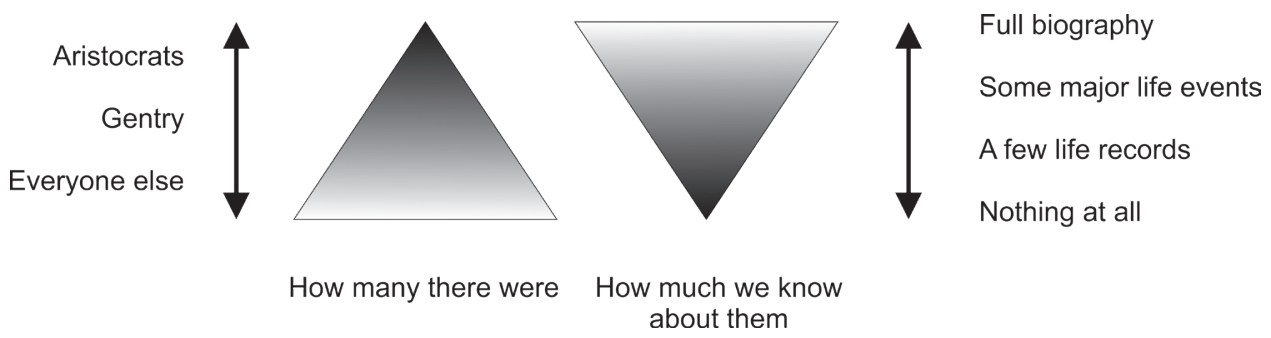

Figure 1. Medieval England: the inverse relationship between level of historical knowledge and an individual's social position. 
high-profile cases such as Richard III (Buckley et al. 2013), what makes the osteobiography a "real" biography, rather than just the study of a random skeleton, is the act of identifying the skeleton with a specific historically documented individual.

We advocate dethroning the textual individual as the gold standard biography. We define biography as the life story of a specific individual, without presuppositions about what specific information it must contain and what methods are used to achieve it. Thus, biographers have the same challenge as any other analysts. Different sources, like different scanning technologies, yield different pictures. Consider an X-ray, a genotype, a family story, and a photograph. One is not "truer" than another. Instead, they are based on different methods, reveal different aspects of someone, and are useful for different purposes. This point was made graphically by Sir John Sulston, the Nobel laureate who founded the Human Genome Project, when he proposed two autobiographical portraits of himself: a photograph and a genotype.

Osteobiography has already proved its value in providing "a past with faces," a past in which all people, rather than just textually privileged ones, have humanity and agency rather than remaining "faceless blobs" (in Tringham's [1991:94] memorable phrase). Landmark osteobiographies are reviewed in the introduction above and in the articles in this issue; for medieval England osteobiographical approaches have been advocated by Gilchrist (2012:43-67; see also Knüsel et al. 2010, and medieval examples from the Netherlands [Arts 2003], Norway [Hamre et al. 2017], Cyprus [Baker et al. 2012], and Poland [Matczak and Kozłowski 2017]). Our goal in this article is not only to provide another example, useful though that would be. Rather, by explicitly comparing skeletal and textual biographies, we wish to explore how they create different kinds of life stories.

This article compares two people who lived and died around the same time-the earlier thirteenth century-and in the same place, a neighborhood about 200 meters across in Cambridge, England. One is known through historical records, and the other is an excavated skeleton. They spoke the same language, Middle English; shared a cosmological frame of reference, medieval Christianity; and would have had many of the same thoughts and preoccupations. They may have known each other or jostled in the marketplace. They were buried in the same cemetery. They may have been related. But when we investigate them through textual biography and osteobiography, very different understandings of them emerge. We will argue that, for understanding the lives of the medieval poor, and indeed the vast bulk of humanity in almost any period, osteobiography provides a more detailed, reliable, and insightful life story than textual biography.

\section{Medieval Cambridge}

By the early twelfth century, Cambridge was a medieval town of ca. 90 hectares (Fig. 2; Bryan 1999; Cam 1959; Lobel 1975; Taylor 1999). Records from 1279 show that, by then, it contained around 440 domestic houses, 60 additional houses in outlying suburbs, around 50 vacant properties, and 75 shops or booths. This documentation suggests a population of ca. 2500-4500. It was a medium-size market town in which economic life was based upon farming and river trade up and down the Cam. It had a castle, and a substantial clerical population based in the Benedictine nunnery of St. Radegund, the Hospital of St. John, and the outlying Barnwell priory and leper hospital. More friaries were founded later in the thirteenth century. The university was founded in ca. 1208-1210, but it did not become a major force in the town until the late thirteenth to early fourteenth centuries. In the period discussed here, its major effect upon the town probably was to add a steady demand for food, drink, and services to support a few hundred clerics and students.

Burial in medieval Cambridge was organized around the religious landscape. In the late twelfth and early thirteenth centuries there were 14 parish churches in Cambridge, each anchoring a neighborhood of a few hundred parishioners. Both of our subjects were buried at the Hospital of St. John, located adjacent to the parish of St. Clement in the north end of town where the main north-south road crossed the river Cam. This parish held 35 domestic houses and five shops and booths. Its several hundred residents were a broadly representative cross section of society. The parish church cemeteries were the normal place to be buried, but people were also buried in religious houses of various kinds, including the Hospital of St. John. From 1144 to 1275, Jews were buried in Jewish cemeteries. Of all these burial options, only a few have been investigated archaeologically. At the parish cemetery of All Saints by the castle north of the river, ca. 220 townspeople buried ca. 950-1365 have been excavated (Craddock and Gregory n.d.), and nearly 40 skeletons, mostly of friars, recently have been excavated at the Augustinian friary south of the marketplace (Cessford 2017).

The most extensively investigated cemetery is at the Hospital of St. John, where approximately 400 burials were excavated (Cessford 2012; 2015). St. John's Hospital was a small charitable institution that provided shelter to poor and indigent people. It was founded around 1195 and lasted until 1511 (Cessford 2015; Rubin 1987; Underwood 2008). The hospital itself initially supposedly consisted of the "poorest of shacks" (pauperrium bordam) erected on a valueless piece of waste ground, but it soon acquired a stone chapel, accommodation for the brethren, a dormitory for inmates, 


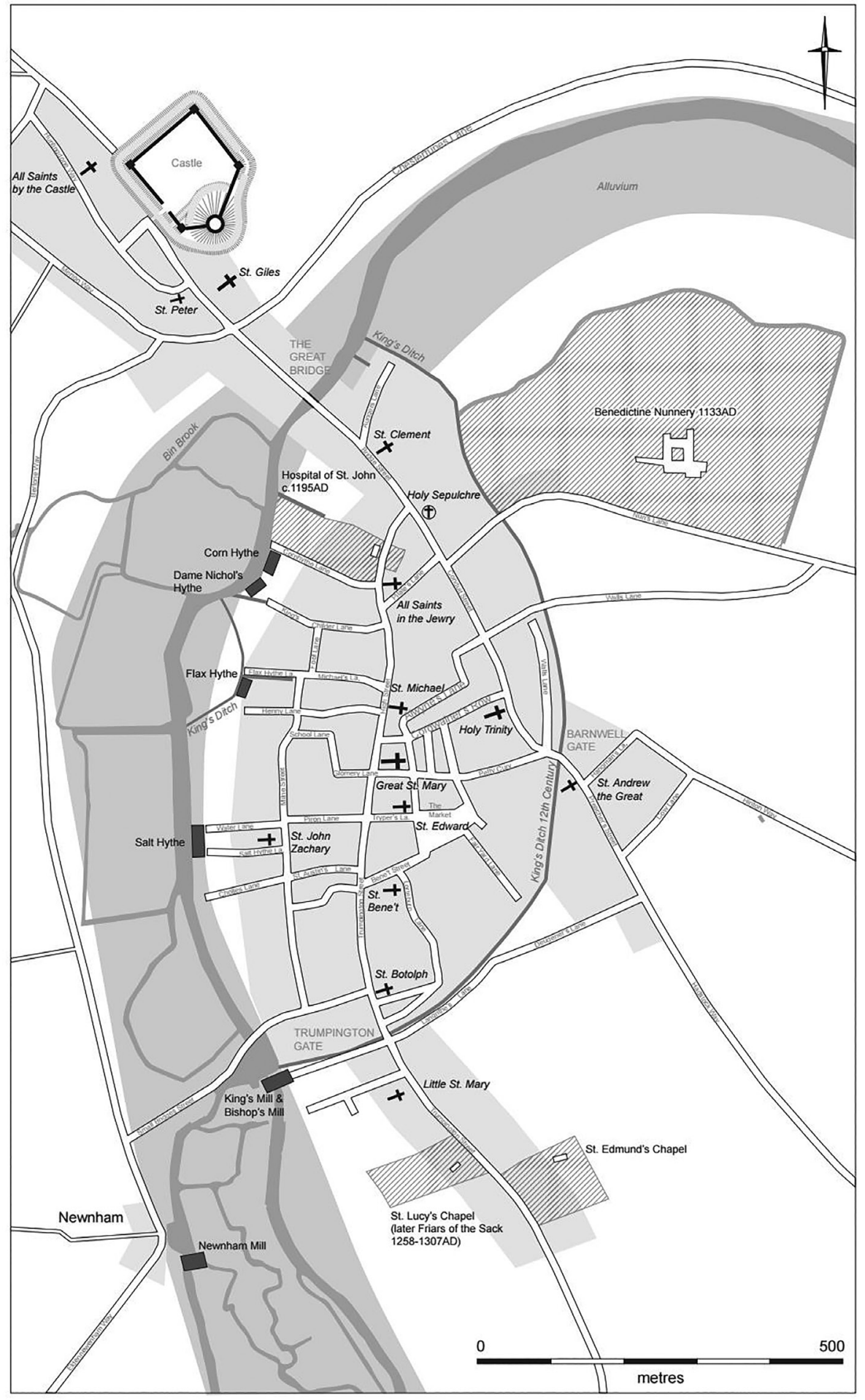

Figure 2. Cambridge in the early thirteenth century (map by Vicki Herring).

ancillary structures, and a cemetery (Rubin 1987). In the usual medieval pattern, it was supported by income from parish churches and from rent-yielding urban properties and agricultural land. These properties were donated to the hospital by the pious in return for prayers and masses. It provided room, board, and clothing for its dozen or so fortunate inmates, who were chosen from the town's poor and infirm. Medieval hospitals provided charitable shelter for many distinct categories of people, including the poor and aged, pilgrims, and the chronically ill (Prescott 1992). Hospitals also provided the necessary setting to have a "good death," with ready access to confession and masses around the dying person's bed (Rawcliffe 
1995). Although the concept of the "good death" was only fully expressed in the fifteenth century, when the Ars moriendi (The Art of Dying) was published, it is clear that there had been an increasing elaboration around death linked to the developing concept of Purgatory, with a distinction between an "idealised and studied good death" and an "unregenerate and impenitent one" (Crouch 1997:180). On current bioarchaeological evidence (Inskip et al. in prep), Cambridge's Hospital of St. John sheltered a combination of older individuals, perhaps unable to work owing to age, weakness, or chronic illness, and younger people with chronic debilitating illnesses. It also housed a few corrodians, older people who had donated property to the hospital in return for guaranteed room and board for the rest of their lives. Among the dead buried in the cemetery there were also some townsfolk (such as Robert Curteis, below) and perhaps some of the hospital lay staff, such as cooks, bakers, and maltsters.

\section{Robert Curteis: A Textual Biography}

Of the tens of thousands of people who lived and died in Cambridge during the thirteenth century, only a minuscule proportion is mentioned in historical records. Children, probably about half the population at any time, are almost entirely invisible. Adult women appear infrequently, mostly when they owned property in their own right. Aside from a few major landowners or civic figures, even adult males emerge only if they were householders subject to taxation, bought or sold property, or fell afoul of the law. Anybody actually named in any textual record, therefore, already has far-above-average historical visibility. One such person was Robert Curteis, who lived in St. Clement parish in the late twelfth and early thirteenth centuries (Faber 2006:321-322). We have chosen him because his level of historical documentation is typical of the minority of individuals mentioned historically, and his family seems to have been economically representative of the neighborhood. Somewhat unusually, he is one of only two townspeople textually documented as being buried in the cemetery of the Hospital of St. John (Fig. 3), making him a compatriot (at least in death) of Feature 958 and others of the skeletal sample under study.

Table 1 summarizes Robert Curteis's available life records, drawing both upon the Hospital of St. John's records (Underwood 2008) and upon Faber's (2006) exhaustive family-by-family study of the parish of St. Clement. Robert Curteis is actually mentioned by name only twice: once as a witness to a neighbor's minor legal transaction, and once in the document that notes his burial place (Fig. 3). We can build something of a family history from references to his paternal

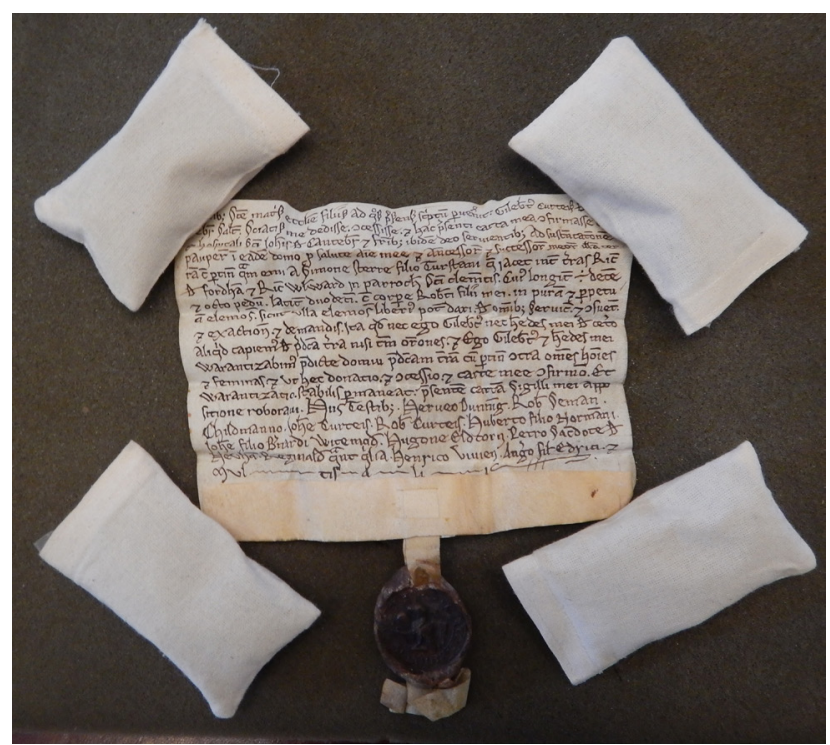

Figure 3. Robert Curteis: the principal life record (SJCA D18.23). This document in the archives of St. John's College, Cambridge, records, among other transactions, his father's gift of land to St. John's Hospital in return for the burial of Robert's body there. Used by permission of the Master and Fellows of St. John's College, Cambridge.

grandfather, who was referred to as Curteis "at the Bridge"; his father, Gilbert; and his son, Peter. The name "Curteis," or "Curtis," an Anglo-Norman word meaning "a man of good education or manners," began to be used in England in the twelfth century, becoming widespread by the thirteenth (Reaney and Wilson 1991:121). Gilbert's, Robert's, and Peter's lives span the transition when ordinary people began to have fixed inherited surnames, often patronymics as in this case. For all of them, their dates of birth can only be estimated by calculating backwards from events such as legal transactions or parentage at which point they must have been adults. Except for Robert himself, their date of death is also entirely inferential.

Robert's grandfather, father, and uncle were townspeople who owned small houses in a crowded neighborhood at the north end of Cambridge. They also owned small parcels of land in the town fields that surrounded Cambridge. They did not own enough farmland to support a family as full-time farmers, and we do not know if they cultivated this land themselves or let it out for rent. They did buy other small urban plots, conforming to the medieval pattern in which property was the basic form of wealth and savings were invested in holdings that would yield rent. We do not know where they came from or what their occupations were. A few of their neighbors are identified by place-names or trade names such as "baker" or "fisher," but most are not. Economically, the family seems to have been typical of their neighborhood. St. Clement's parish contained about 100 households paying tax, plus an unknown number of households 
Table 1. Robert Curteis: the textual record. Items in italics are not directly attested by textual records but are inferred from events textually attested, such as transactions implying that the person in question was legally an adult at a given date. SJHC denotes documents listed in the Cartulary of the Hospital of St. John (Underwood 2008).

\begin{tabular}{|c|c|c|}
\hline Approximate Date & $\begin{array}{l}\text { Robert's } \\
\text { Approximate } \\
\text { Age }\end{array}$ & Event \\
\hline Before 1170 & - & Robert's grandfather, Curteis "at the Bridge," is born. \\
\hline $1160-1180$ & - & Robert's father, Gilbert Curteis, and uncle, Richard Curteis, are born. \\
\hline $1180-1200$ & 0 & Robert Curteis is born. \\
\hline Ca. 1200 & & $\begin{array}{l}\text { Curteis "at the Bridge" is a bailiff, pays fines, and witnesses various minor legal transactions implying } \\
\text { he is a responsible adult (Faber 2006:321). }\end{array}$ \\
\hline Ca. 1200-1211 & & Curteis "at the Bridge" dies. \\
\hline Early 1200 s & - & $\begin{array}{l}\text { Robert's father, Gilbert, and uncle, Richard, are adults, witnessing a neighbor's legal transaction (SJHC 5) } \\
\text { and owning seven acres of land in fields around the nearby village of Maddingley (SJHC 196-97). }\end{array}$ \\
\hline 1211 & $10-30$ & $\begin{array}{l}\text { Along with many neighbors, Robert's father, Gilbert, and uncle, Richard, are taxed ("amerced"); this } \\
\text { implies that their father, Curteis, is dead and they are the householders in the family. They pay two marks } \\
\text { each, approximately modal for taxpayers in their neighborhood of Cambridge and about a third to a half } \\
\text { of a laborer's annual wage (Faber 2006:321, 808). }\end{array}$ \\
\hline Early 1200s? & $20-40$ & Robert is an adult, witnessing a neighbor's land transaction (SJHC 101-02). \\
\hline $1200-1220$ & $20-40$ & Robert's son Peter is born. \\
\hline $1200-1220$ & $20-40$ & $\begin{array}{l}\text { Later tax lists (the Hundred Rolls of 1279) imply that Robert bought at least one plot of land in St. Clement } \\
\text { parish; his son, Peter, inherited this from him as well as another plot either inherited from Robert or } \\
\text { directly from Gilbert (Faber 2006). }\end{array}$ \\
\hline 1219 & $20-40$ & $\begin{array}{l}\text { Robert's father, Gilbert, and uncle, Richard, are taxed ("tallage"), implying that they are the responsible } \\
\text { heads of household (Faber 2006:321, 809-10). Richard pays } 1 £ 4 \mathrm{~s} 8 \mathrm{~d} \text { and Gilbert 15s, again approximately } \\
\text { modal for their neighborhood. }\end{array}$ \\
\hline Ca. $1220-1230$ & $25-45$ & $\begin{array}{l}\text { Robert Curteis dies. His father, Gilbert, still living, gives a piece of riverside land approximately } 3.65 \text { by } \\
5.50 \mathrm{~m} \text { to the Hospital of St. John in return for being able to bury Robert in the hospital cemetery } \\
\text { (Faber 2006:321; St John's College Archives D18.1.23). }\end{array}$ \\
\hline 1246 & - & $\begin{array}{l}\text { Robert's son, Peter, gives up rights to seven acres of fields around the nearby village of Maddingle } \\
\text { (SJHC 200). He owns at least three properties in St. Clement's parish (Faber 2006:321-22). }\end{array}$ \\
\hline 1260 & - & $\begin{array}{l}\text { Robert's son, Peter, owns property at least to 1260, implying he is still living. He does not appear in records } \\
\text { after this date and his properties belong to other people, implying that he had no male heirs } \\
\text { (Faber 2006:321-22). }\end{array}$ \\
\hline 1279 & & $\begin{array}{l}\text { No male members of the Curteis family are mentioned as owning property in Cambridge when the } \\
\text { Hundred Rolls are compiled. }\end{array}$ \\
\hline
\end{tabular}

too poor to do so. Robert's father, Gilbert, and his uncle, Richard, were both among the townspeople who paid taxes, including an amercement in 1211 and tallage in 1219 (Maitland 1898:167-170). In both assessments they were close to the median amount paid in their parish. However, tax was assessed for only $20-30 \%$ of households (149 of about 500 in 1211, 92 of about 500 in 1219). As taxpayers, the Curteis males were firmly ensconced in the middle range of the burgess class, the property-owning freemen of the town, and belonged to the uppermost $10-20 \%$ of adults overall. They were ordinary townsfolk, probably working with their hands in a craft or trade, but certainly not poor.

Robert's own life course is even more inferential. Robert was almost certainly born between 1180 and 1200. He was not taxed as a head of household in 1211 or 1219, but his father was, implying that Robert still lived in his father's house at that point, perhaps as a young man who was born in the 1190s. He lived long enough to buy or inherit a house plot and to have an acknowledged son or heir, Peter, suggesting that he also married. We know when Robert died with more precision. Between about 1220 and 1230, Gilbert is recorded as donating a very small (ca. $3.65 \mathrm{~m}$ by $5.50 \mathrm{~m}$ ) piece of riverside land to the Hospital of St. John in return for burying Robert there. Assuming that Robert was born in the 1190s, he would have died around 30 years of age, probably leaving a young son, Peter, who inherited both a house plot from him and property from Gilbert. The transaction between Gilbert and the hospital at Robert's death is interesting in itself. The hospital was permitted to bury its own members, servants, and the inmates in its care. It could also bury others who asked to be interred there in writing, but the hospital then had to pay a fee to the deceased's parish church (Rubin 1987:106). Robert would normally have been buried in the graveyard of his local parish church, St. Clement's. Why would Robert be buried at the hospital cemetery? While burial in monastic cemeteries was a prestigious act in 
the later Middle Ages (and one that was usually paid for with a substantial donation), at this point being buried in the cemetery of a young hospital with its mission of care for the needy was unlikely to be a status-oriented move. Rather, in the early to mid-thirteenth century the townspeople of Cambridge considered the hospital an establishment that they had founded and created (known as a hospitale simplex or locus privatus), rather than a more formal religious institution (locus religios; Rubin 1987). As Robert had lived within $200 \mathrm{~m}$ of the hospital for all or most his life, there may have been a close familial attachment. Hospitals also provided the necessary setting to have a "good death," with ready access to confession and masses around the dying person's bed (Rawcliffe 1995). Whether this burial location implies that Robert was outstandingly pious or an exemplary sinner in need of help is conjectural. The document itself does not specify whether his burial was in the hospital cemetery among the inmates or in a higher-status position near the chapel. That the piece of donated land was so small probably indicates nothing about the family's economic status, but simply that it was an infrequent transaction at that point, without an established scale of cost. It seems likely that the land was an adjacent scrap that conveniently filled in a gap in the hospital's riverside access.

As a textual individual, "Robert Curteis" consists of a name, a sex, a general economic class identification, and a general identification with a place. These provide orientation points for extrapolating much more. While no gender system is entirely binary, for the medieval period, identifying somebody as a social male strongly suggests that this individual was biologically identifiable as male, and it suggests a strongly conventionalized identity and activity regime. We can infer a legal status: a free person not tied to a feudal manor. This information sketches in a series of rights and obligations. For instance, Robert would have been free from corvée demands, but owed taxes upon his property. Placing Robert as an urban man from a moderately prosperous family suggests that he was probably a craftsman or tradesman rather than a general laborer. $\mathrm{He}$ and his male line had a four-generation run in the ranks of more prosperous townsfolk, buying a handful of small properties that presumably provided rent income from people still less prosperous. This cycle may have ended due to a lack of further heirs, or their property may have ended up among daughters or collateral relatives; it is almost impossible to trace such links in records of this nature. There are also some interesting starting points for further inference. For instance, Robert lived long enough to act as a legal witness, buy property, and father a son, all acts of a socially competent adult male, but he was never recorded as a head of household. He may have never left his father's household. Alternatively, perhaps he was adroit at avoiding tax assessments, or perhaps his relatively brief social adulthood simply fell between the infrequent tax exactions that form the available records.

This biography has four principal limitations, which can be taken as typical of textual biographies.

1. It relies heavily upon normative generalization to fill in gaps. For instance, we do not really know that, because he was identified as male, Robert conformed to "normal" masculinity. We assume that he participated in medieval Christianity in a "typical" way rather than being indifferent, skeptical, atheistic, or heretical. Similarly, links between people are often more or less inferential. For example, it is sometimes assumed that males with the same surname in successive generations and sometimes holding the same properties are father and son, or at least a straightforward succession of legal heirs.

2. It relies upon an underlying, assumed history of the human body, for instance, in estimating the length of a generation and the level of social activity at different stages of life.

3. It has important social gaps. It really only tells us about heads of households and people engaging in recorded legal transactions. We know almost nothing about women and children, younger sons, servants, and other people (e.g., how large the Curteis household actually was, and whether Robert had siblings or not).

4. Most importantly, even a textual biography much more complete than this one categorically remains silent on many aspects of human experience. It is uncommon to know the occupation or actual daily activities of anyone other than a cleric who is mentioned in textual records of medieval Cambridge. Similarly, we rarely know of their origin or movements in life, their appearance, or their individual diet or health experience and life risks.

It is also worth noting how little relationship this life story bears to any of the dramatic or important regional or national events between 1190 and 1225 . Nationally, Richard I was succeeded by King John (1199), Jews were permitted to live freely in England (1201), and a harsh winter created famine (1205). King John was excommunicated by the pope in 1209, involved in the First Barons' War, and forced to sign the Magna Carta (1215-1216), and was succeeded by Henry III (1216). Locally, Cambridge obtained a town charter (1201), a nationally important fair (1211), and royal visits (1215-1216), and scholars arrived from Oxford to begin university teaching (1208-1210). None of these events are visible in the Curteis' family saga. For ordinary folk, wars and dynastic politics mostly happened 
somewhere else far away. Major famines and local events must have impinged on their lives, but none of these can be readily traced in the individual lives, whether of survivors or casualties.

\section{Feature 958: An Osteobiography}

Feature 958 (F958) is the skeleton of an adult male excavated in the cemetery of the Hospital of St. John, Cambridge. F958 presented a complete, fully articulated skeleton (Fig. 4). He was chosen for osteobiographical reconstruction because he is an older individual with a very well preserved skeleton (Figs. 5-6). Moreover, for this article we wanted an adult male to provide a relevant comparison for Robert Curteis, since our ability to write textual biographies of women from medieval Cambridge is almost nil. F958 was male, according to both skeletal criteria (pelvic and cranial indications) and aDNA evidence. Based upon both pelvic traits (following standard protocols in Buikstra and Ubelaker [1994], as validated in Inskip et al. [2018], these included the public symphysis [Brooks and Suchey 1990] and auricular surface [Buckberry and Chamberlain 2002]) and advanced dental wear (Brothwell 1981), he died between 40 and 60 years of age.

F958 is currently modeled as having a 95\% probability of having died between 1222 and 1290, based upon Bayesian calibration of direct AMS dating of his skeleton. As he was between 40 and 60 years old when he died, there is a $95 \%$ probability that he was born between 1174 and 1236, and a $68 \%$ probability that he was born between 1195 and 1231. If we place him toward the middle of his chronological range and ageat-death distribution, we might imagine him as born around 1200 and dying around 1250 . If so, he would have been a child or young man when Robert Curteis was an adult. He, thus, outlived Robert both in lifespan and chronologically.

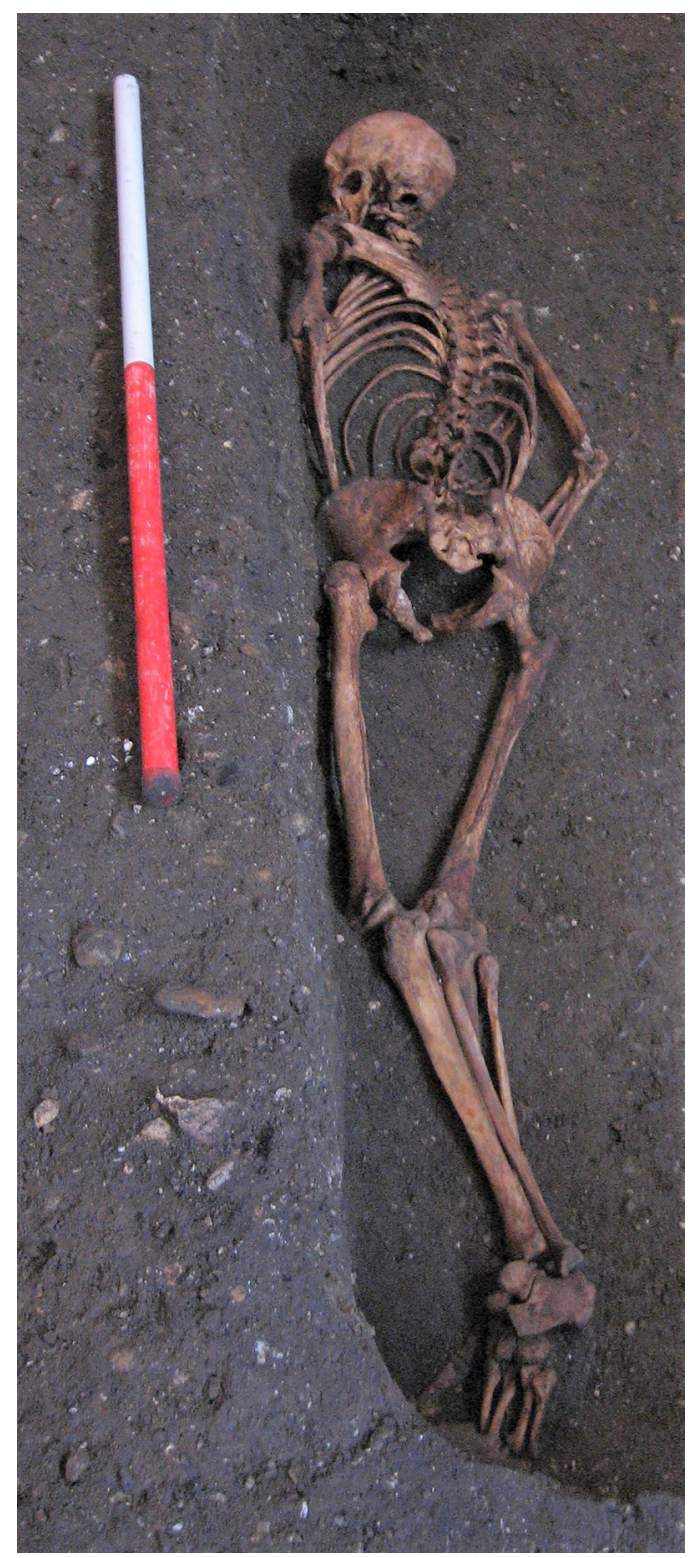

Figure 4. Feature 958, excavated (photo: Cambridge Archaeological Unit).

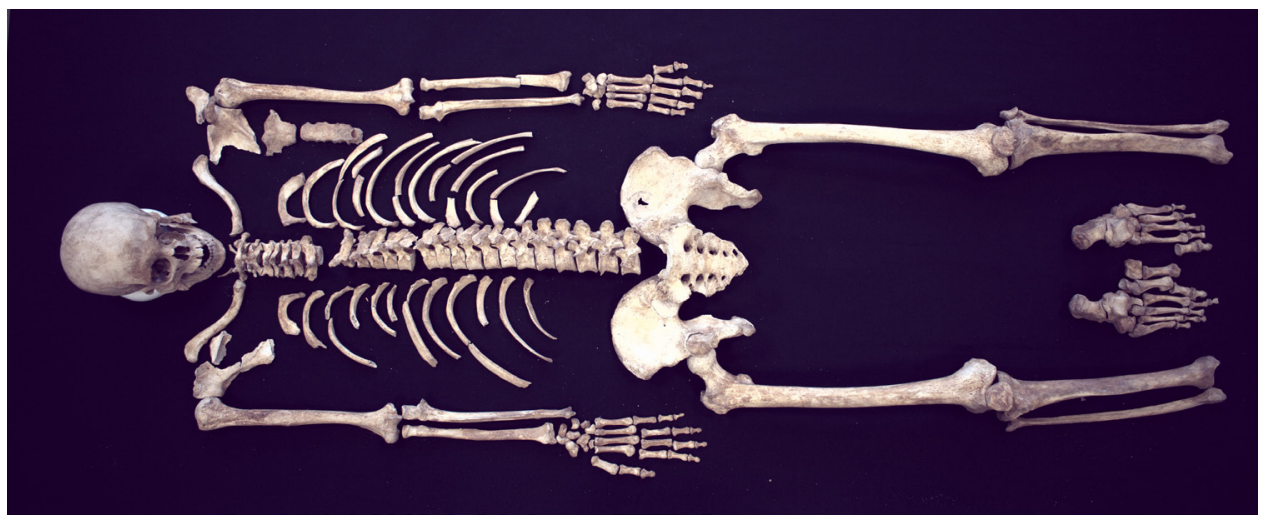

Figure 5. Feature 958: the principal life record (photo by John Robb). 


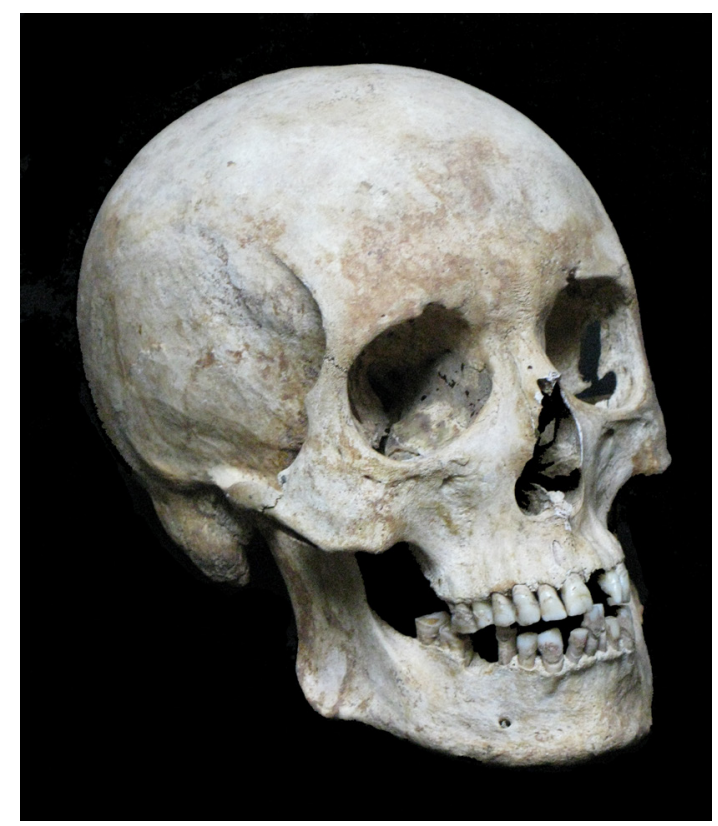

Figure 6. Feature 958: skull (photo by Craig Cessford).

We can summarize the salient facts to be learned from F958's skeleton succinctly, arranged as far as possible in chronological order.

- F958's genetic heritage is completely unremarkable for the region. While higher-resolution scans are ongoing, his mtDNA lineage is $\mathrm{H} 2 \mathrm{~A}$, which is extremely common for the British Isles.

- His childhood must be considered a success. Linear enamel hypoplasias upon his anterior teeth reveal at least two intervals of interrupted growth between 0 and 6 years of age. It is unknown how serious a stress is needed to produce such lesions, and it may have been quite minor-a short bout of childhood illness, for instance. If he suffered from conditions that result in cribra orbitalia, a very common finding in the St. John's sample, he lived long enough to remodel all trace of it. He does not show evidence for rickets, which is evident in others in the cemetery. Moreover, he survived childhood, unlike perhaps half his birth cohort (based upon general comparison with premodern demographic profiles; see Fleming 2006), and he reached an adult stature above the average for males buried in the cemetery.

- His adult stature was approximately $177.5 \mathrm{~cm}$, estimated using the Trotter and Gleser "white" equations (Trotter and Gleser 1958). His height is well above the average stature of $167-168 \mathrm{~cm}$ for adult males in this sample (Dodwell in Cessford 2015). With above-average but not extreme height and at least average robustness, he would have fit well into the cohort of adult males.
- F958's collagen carbon isotope value (-18.7) is typical for the St. John's group, and for medieval English samples in general (Price 2013). However, his nitrogen isotope value (14.7) is among the highest for both the St. John's Hospital group and for medieval England generally (Fig. 7; Price 2013). This result suggests that his diet contained a significant proportion of animal protein and/or fish, particularly in the last decade or two of life, the interval presumably represented by the analyzed rib sample. Food in medieval England was strongly related to social class, with poorer people subsisting largely on bread, ale, and vegetable pottage. Inmates of St. John's Hospital were supposed to receive meat several days a week, and fish at least once a week (Rubin 1987). However, F958's carbon and nitrogen isotope values relative to those of the rest of the hospital skeletal sample suggest perhaps that he had not spent many years within the hospital, but in settings with more privileged access to food.

- He displays 12 Schmorl's nodes in thoracic and lumbar vertebrae; these lesions indicate places where bone has resorbed around a herniated intervertebral disk. Schmorl's nodes are common, both in the St. John's Hospital sample and generally in premodern populations. If they do not impinge upon a joint surface or nerve, they do not necessarily indicate any clinical symptoms such as pain or limitation of activity (Faccia and Williams 2008). Unlike osteoarthritis, Schmorl's nodes are often found in younger as well as older adults. However, manifesting them in almost every vertebra in the central and lower back suggests significant accumulated functional stress, perhaps related to work activity.

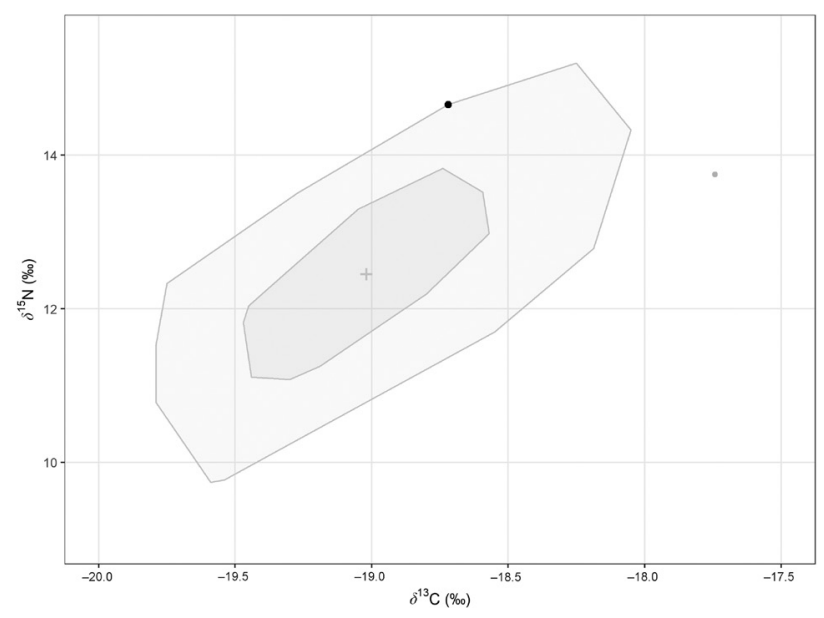

Figure 7. Carbon and nitrogen isotopic values for adult Saint John's Divinity School samples. Feature 958 is marked with a black dot. Gray cross indicates median values, and the dark gray area ("bag") contains $50 \%$ of the samples. The outer gray loop is three times the size of the "bag," and anything outside it is considered an outlier (chart by Alice Rose produced following Rousseuw et al. 1999). 
- F958's bones show entheseal markings typical of a male of advanced age in this group, suggesting that he was physically active without impairment from any long-term chronic illness. The most distinct evidence of activity in his skeleton consists of modifications to his feet (Fig. 8). These alterations involve inferior extensions to the distal articular surfaces of almost all metatarsals, reflecting a habitual posture in which the toes were strongly flexed beneath the feet. At the same time, the proximal phalanges display flattened facets on their distal articular surfaces, suggesting that the toes were extended under pressure. The modifications are bilateral. The ankles and hips show no sign of so-called "kneeling facets," "squatting facets," or hyperflexion at the hips. This posture is unusual and would not result from habitual kneeling or from riding with the feet held in stirrups, for example. While we do not know what activity would involve this position, it was sustained enough to result in skeletal modifications in a pattern distinct from others in the sample. This observation suggests that F958 may have been a specialized worker of some sort rather than a general laborer.

- He suffered from ongoing dental disease, with periodontal disease, five posterior teeth lost before death, and two abscesses. This dental pathology is typical for someone his age in medieval Cambridge, and dental problems would have been recognized as part of the normal life course, particularly in older people. No effective therapy was available other than removing the offending tooth. Dental disease would not have limited his ability to eat a varied diet, as he would simply have shifted chewing

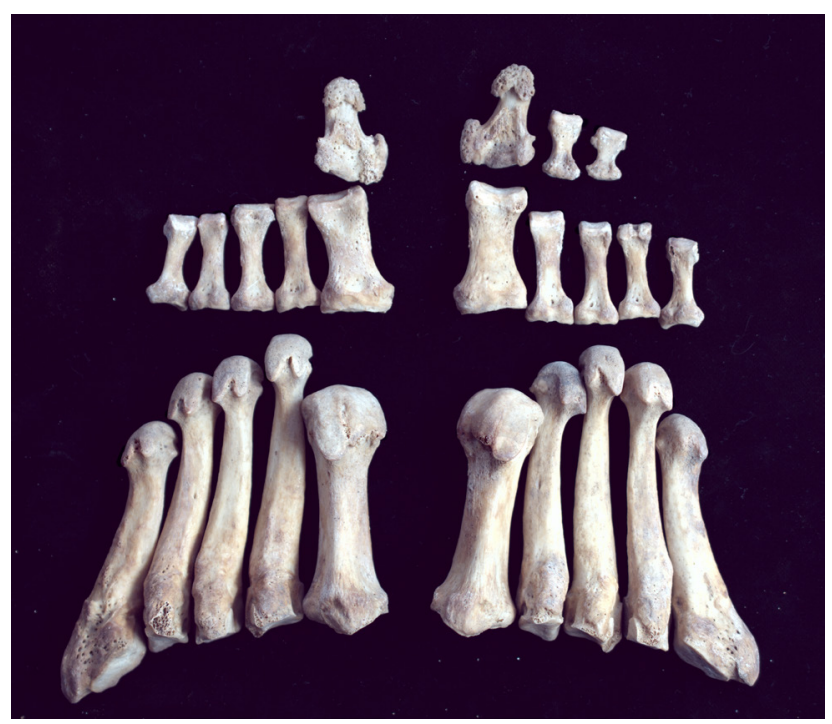

Figure 8. Feature 958's feet (plantar view); note extensions to the heads of most metatarsals, and flattened facets on the heads of proximal phalanges (photo by Sarah Inskip). forward to his surviving molars, premolars, and anterior teeth. Dental wear on his remaining teeth is very even. However, with untreated dental problems of all kinds, he would certainly have experienced sometimes prolonged episodes of perhaps severe pain.

- He suffered two minor traumatic injuries in his lifetime, both of which healed completely without any apparent skeletal complications: a fractured left rib, and a small depressed fracture in the posterior area of his left parietal. Both could plausibly have resulted either from accidental causes or violence. Traumas from both lesion types were more common in medieval males than females (Grauer and Miller 2017). Both would have caused pain and tenderness for some time but could have healed without medical intervention and without changing his appearance noticeably.

- F958's metatarsals exhibit characteristic lesions of incipient gout, in the form of very small erosive lesions on the medial sides of both MT1 heads. Gout was relatively common in medieval Cambridge, including in the St. John's Hospital sample, with multiple individuals showing pathognomic signs of the condition. It may have been caused by a combination of diet, exposure to lead, and genetic background. Gout was recognized by medieval people. This condition may have led to episodes of pain, particularly in the feet, and limited mobility.

- F958's leg bones (both femora and tibiae, on both sides) exhibit extensive, fine, active periosteal bone deposition on their midshafts. This pathology is non-specific. While it seems likely that it originated in some systemic infection, no differential diagnosis is possible. However, it does suggest that he suffered from chronic, low-level illness of some kind. Its experiential symptoms are unknown.

A common feature of conventional biographies is providing images of the biographee to transform him or her from a textual individual to a visual one whom the reader can imagine as a person. Being able to provide such an image is a major asset to biographical materials. F958's skeleton provides us with the necessary material. His facial features were distinguished by a relatively gracile brow but a strong, markedly flared jawline (Fig. 6). A facial reconstruction using standard forensic methods (Wilkinson 2004), and with a choice of beard and hair aimed at the middle of the range of possibilities, reveals an unremarkable, pleasant, masculine face (Fig. 9). Going further, how does such an image relate to F958's everyday appearance? Particularly for subjects before recent centuries, almost all available biographical images are formal portraits, normally posed and in full regalia, often made quite late in life. They were not intended to present someone's 


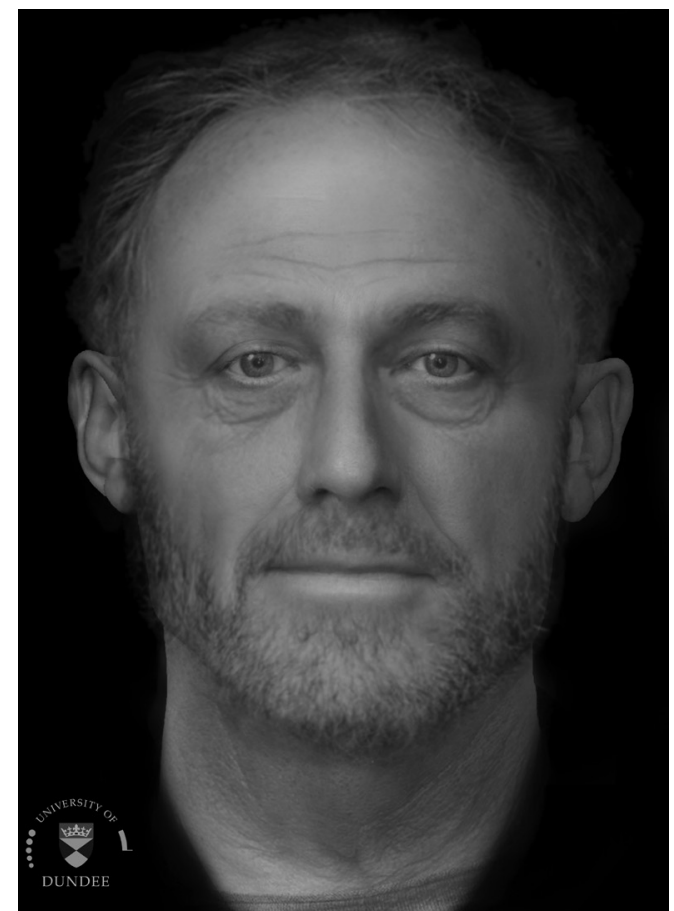

Figure 9. Facial reconstruction of Feature 958 (image: Chris Rynn, University of Dundee).

appearance in ordinary life and activity, and they normally seem quite distant from it. Much the same is true for an expressionless, decontextualized, formal forensic reconstruction. Figure 10 presents a complementary approach. As with all forms of biographical interpretation, it helps us think about specific dimensions of the subject's life. Rather than focusing on highlighting individuating physical details (other than a hint of a prominent gonial angle), it focuses upon motion, activity, and social context (the streets of Cambridge, some specialized manual work placing stress on the back, a basket potentially of foodstuffs) and is set some time before decline and death.

Although the Hospital of St. John may have housed a few paying inmates (corrodians), and a few noninmates may have been buried in its cemetery, the overwhelming probability is that F958 was an inmate of the hospital. How might he have ended up there? The hospital housed a heterogeneous population, including a mixture of young, chronically ill people and older people who presumably needed shelter due to a combination of age, infirmity, and lack of family support. It may also have contained a few aged and indigent scholars. We have built a picture of F958 as a robust, physically active person who formerly may have pursued a specialized manual craft or trade, and most of his health problems were common in older age. General indicators of decrepitude-particularly tooth loss, back problems evidenced in stooping, and

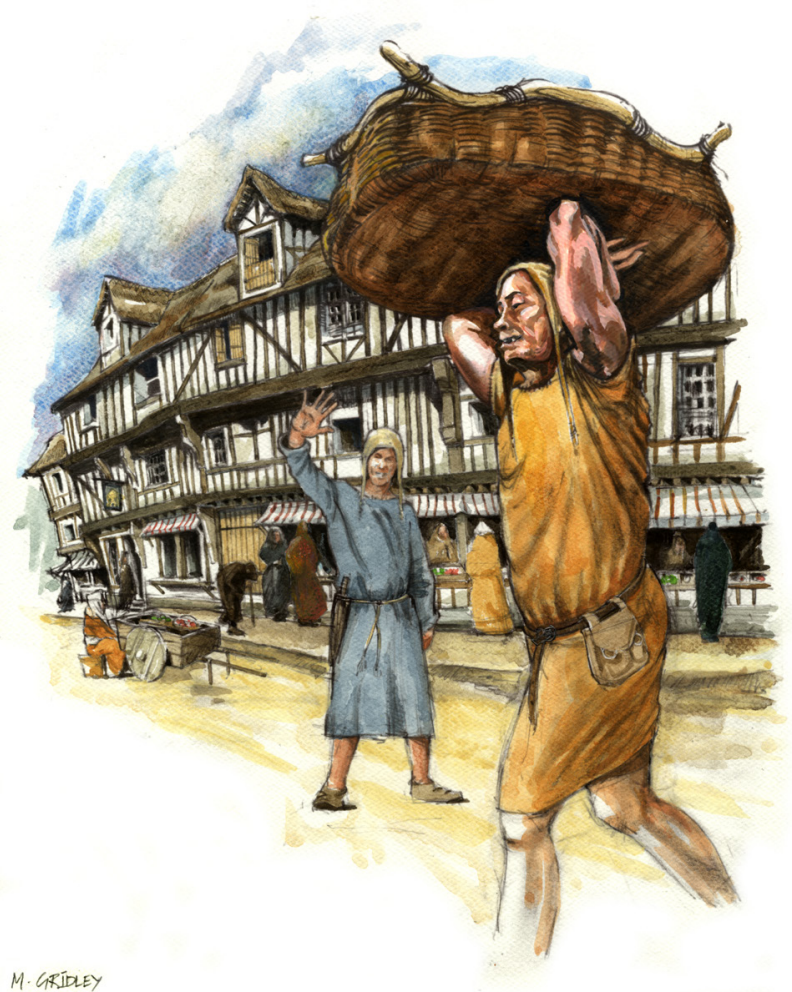

Figure 10. Reconstruction of Feature 958 in life, some decades prior to his death (picture by Mark Gridley).

disability—-were recognized as signs of advancing age, for instance in visual characterizations of the later "ages of man" (Gilchrist 2012). It is possible that he became an inmate of the hospital because of age-related inability to work, lack of family networks, and the resulting indigence rather than because of any specific medical problem.

There is no indication of what caused F958's death. He lacks any sign of lethal trauma or of tuberculosis or leprosy; preliminary screening has not revealed any pathogen aDNA. The burial is peculiar in two ways: the grave cut is unusually deep $(0.84 \mathrm{~m}$, in contrast to an average of $0.4-0.6 \mathrm{~m})$. Contrary to almost universal practice in medieval England, the body was deposited face down. Prone burials are rare, but about a dozen cases are known in medieval England and Scotland (Gilchrist and Sloane 2005:153-154). There is no consensus about what they may connote, with hypotheses ranging from premature burial of someone still alive to postmortem disturbance or response to an unusual body. It has been suggested that prone burial may represent a penitential gesture. The only evidence of this practice is an account from twelfth-century France describing a royal burial three centuries earlier, so how widespread a practice this was in thirteenthcentury England is hard to assess. The most likely 
interpretation here seems "casual or hurried burial" (Gilchrist and Sloane 2005:154), perhaps related to depositing a body completely wrapped in a shroud within a deep grave.

This osteobiography already provides quite a full and varied set of "life records" Using these facts to construct a life narrative involves a delicate balance of probability and generalization. Some likely inferences include:

- What F958 probably looked like.

- That he suffered periods of pain from chronic conditions such as dental disease in a world without much effective anesthesia.

- That 958 was likely a manual worker rather than a cleric based on the functional stress found in his spine. Most clerics who also worked manually (e.g., some monks and friars) had their own institutional burial grounds elsewhere in Cambridge.

- F958 probably habitually performed some unusual, repetitive gesture or posture, perhaps with functional stress, based on the idiosyncratic functional modifications of his toes. Thus, he may have had a craft or trade rather than being a generalized laborer performing the same range of activities that others did.

- As a chosen recipient of generous institutional charity in a sea of the urban needy, he must have been seen as deserving and conventionally religious. (This selection, incidentally, gives us some guarantee that his sex and the gender ascribed to him coincided conventionally; it is unlikely that a charitable religious institution would have admitted someone not conforming to gender norms.)

Bringing these pieces together suggests more complex scenarios. For example, given that the basic way of supporting the old and infirm was within family networks, was F958 the last of his family? Given that his isotope values do not converge with those of his fellows, did he live in the hospital for only a few years at most? He appears to have eaten a diet rich in meat or fish in a period during which poor people largely subsisted upon bread, ale, vegetables, and a few dairy products. Yet he was buried in a charitable institution that housed people unable to care for themselves. He, thus, appears either to have been eating above his station, or was buried below it. Possible backstories for this situation might include the following:

- He was previously more prosperous but had come down in the world (illustrating the vicissitudes of "Fortune's Wheel," in medieval parlance).

- He previously worked at some manual trade involving access to richer-than-normal food (a merchant selling provisions, a butcher, a fisherman).
- His need for shelter was not based upon poverty but on other factors such as general decrepitude and a lack of family.

In the hyper-precise world of Sherlock Holmes, in which individuals always substantiate the obvious generalities, every retired sailor conveniently has an anchor tattooed on his arm, and all facts are tightly connected to a single plot, we might imagine F958 as a retired, formerly prosperous fisherman, butcher, or food merchant, a man of conventional and pious disposition, who has become unable to work through age and infirmity and who suffered family losses that left him on his own. Thus, he was taken into a poorhouse. But our evidence does not exclude many alternative, if less probable, scenarios, for instance, that he was a lay servant of the hospital who ate at the staff table but was buried in the common cemetery. Or he could have been a neighbor who bought his way into the hospital either while living, as a corrodian, or after death through a donation in return for burial there, like Robert Curteis. In both osteobiography and biography, part of the art is knowing when to stop.

The key point, however, is not whether we can reconstruct his biography in every detail; rather, it is understanding what kinds of insights osteobiography affords. Unlike the ideal textual biography, we do not have name, precise dates, correlation with historic events, or relatedness to specific other people. But we do have some idea of appearance, diet, the experience of health and illness, habitual activity, social treatment at death, and above all some possible life trajectoriesall dimensions of life for which textual biography is normally silent as the grave.

\section{Discussion: Biography, Self-Knowledge, and Bias}

By now, the take-home message should be obvious. While we are predisposed to regard textual individuals as "real" biographies, the gold standard to which other forms of biography should aspire, this goal really misrepresents the situation. Reading the two biographies above, whom do you feel you know more about, Robert Curteis or F958?

Clearly, the situation will vary according to the historical context and the available sources. Using the two biographies presented here as an example, we might summarize the information available for ordinary medieval people as in Table 2. It is obvious that, as with all technologies for scanning and representing people, each method highlights different aspects of an individual's life; there is no single master method to which others serve merely as handmaidens or substitutes. 
Table 2. Sources of information on an ordinary person in medieval England.

\begin{tabular}{|c|c|c|}
\hline & Textual Biography & Osteobiography \\
\hline Name & $\begin{array}{l}\text { A very small number (some better-off male heads of } \\
\text { households, and a few other people) }\end{array}$ & Unavailable without textual aid \\
\hline $\begin{array}{l}\text { Historical dates } \\
\text { (birth, death, etc.) }\end{array}$ & $\begin{array}{l}\text { Rarely known; sometimes inferable for historically } \\
\text { mentioned people to within a generation or so }\end{array}$ & $\begin{array}{l}\text { Available for dated or archaeologically phased skeletons but } \\
\text { usually with a margin of error of one to two generations }\end{array}$ \\
\hline Age & $\begin{array}{l}\text { Rarely known; inferable for historically mentioned } \\
\text { people to within ca. } 20-30 \text { years }\end{array}$ & $\begin{array}{l}\text { Knowable to within } 10-20 \text { years error for adults, more precise } \\
\text { for younger individuals }\end{array}$ \\
\hline Gender & $\begin{array}{l}\text { When somebody is historically attested, gender is } \\
\text { generally clear }\end{array}$ & $\begin{array}{l}\text { Skeletal sex is often available, genetic sex increasingly so, and } \\
\text { social gender can often be inferred }\end{array}$ \\
\hline Individual appearance & Rarely known & Reconstruction of face and body form sometimes possible \\
\hline Religious sentiment & $\begin{array}{l}\text { Rarely known, except through textually attested } \\
\text { pious donations }\end{array}$ & Rarely known, except through variant burial practices \\
\hline Personality & Rarely known & Rarely known \\
\hline Economic status & $\begin{array}{l}\text { When somebody is historically attested, approximate } \\
\text { economic status may be inferred from tax or } \\
\text { property transactions }\end{array}$ & $\begin{array}{l}\text { May be inferred approximately from place and manner of } \\
\text { burial, and from evidence of food consumption }\end{array}$ \\
\hline $\begin{array}{l}\text { Legal status } \\
\text { (e.g., serf, free) }\end{array}$ & $\begin{array}{l}\text { Can sometimes be inferred from legal or } \\
\text { financial transactions }\end{array}$ & Rarely known \\
\hline Activity regime & Rarely known, except by generalization from job titles & $\begin{array}{l}\text { Specific occupations rarely known, but level of work and } \\
\text { idiosyncratic activity patterns may be visible }\end{array}$ \\
\hline Diet, food consumption & Rarely known & Some aspects accessible from skeletal and isotopic evidence \\
\hline Health experiences & Rarely known & $\begin{array}{l}\text { Some aspects accessible in some detail from palaeopathology } \\
\text { and pathogen aDNA }\end{array}$ \\
\hline Life risks, contingencies & $\begin{array}{l}\text { Rarely known, except where inferable from } \\
\text { legal transactions }\end{array}$ & $\begin{array}{l}\text { Sometimes inferable from conjunction of disease, trauma, } \\
\text { consumption, etc., measured at different points in the lifespan }\end{array}$ \\
\hline Relatedness & $\begin{array}{l}\text { Rarely known, except when legal documents or } \\
\text { surnames give clues to parentage or siblinghood }\end{array}$ & $\begin{array}{l}\text { Rarely known, except if place in general population structure } \\
\text { may be reconstructable (aDNA) }\end{array}$ \\
\hline Mobility & $\begin{array}{l}\text { Rarely known, except when first-generation surnames } \\
\text { include place-names }\end{array}$ & $\begin{array}{l}\text { May be reconstructable through isotopic analysis } \\
\text { and/or aDNA }\end{array}$ \\
\hline Cause of death & $\begin{array}{l}\text { Rarely known, except for unusual cases mentioned in } \\
\text { law, medicine, or chronicles }\end{array}$ & $\begin{array}{l}\text { Rarely, except for severe diseases or traumatic injury leaving } \\
\text { skeletal signs }\end{array}$ \\
\hline
\end{tabular}

There are important sectors of human life that are far more accessible through skeletal studies than through textual studies, particularly if we want to understand someone's individuality rather than simply filling in historical generalizations (cf. Fleming 2006).

Comparing the two forms of biography makes an important meta-point about the nature of biography. While a naive view might consider textual biography an arraying of known facts and dates, and osteobiography an interpretive exercise, both are fundamentally interpretive. For traditional textual biographies, this situation is immediately clear not only from comparing competing full-length biographies of public or literary figures but also from how obituaries or entries in biographical dictionaries select which facts to present and how to marshal them to create a headline or story line. The interpretive element in osteobiography is more obvious at first sight, as the genre implicitly or explicitly is expected to supply elements defined by textual biographies, such as names, faces, occupations, and causes of death. (Conversely, and perhaps unfairly, no one considers a textual biography incomplete if it does not report the number of childhood stress episodes as well as the subject's relationship with her parents, her isotopic values as well as her favorite foods, or her genetic relationships as well as her name!) The point is that neither one is a definitive, universal description of a human life; both are selective interpretive techniques with strengths in highlighting specific aspects of life. It thus follows that there is no single cookbook set of rules; how to interpret a life is relative to why you are doing it. Naming a skeleton provides an example. Should we have given F958 a name? As discussed above (Hosek and Robb, this issue), naming humanizes a skeleton and makes it easier to relate to, which is valuable for both public and professionals. However, it also makes a concrete knowledge claim about the skeleton; it can represent a conscious choice about making it familiar or alien; and, as in cases such as "Ötzi," the name can take on a life of its own almost as a quasi-real person to whom the skeleton becomes appended. In some cases, naming a skeleton may be 
justified and productive. Here, as we undertook this osteobiography as an academic form of exploration to test the limits of the method in generating knowledge, we thought it would prove an impediment.

Finally, osteobiography offers three specific and valuable advantages that make it a compelling form of biography. One concerns methodology and intersectionality. Textual and skeletal biographies are methodologically and epistemologically very similar. Each starts with proxy evidence (e.g., isotopic data as a proxy for nutritional status, a tax register as a proxy for household income); each requires a good deal of sifting and construction to build the ensemble of proxies into a life narrative; and each involves constantly tacking back and forth between the specific case and generalities, using generalities to draw out implications but with the risk of normalizing the data and missing individuality. For example, if we know that a given textual or skeletal individual was male, we can infer a great deal about his social identity and activity, but only to the extent that he conformed to conventional norms about maleness. The resulting picture can be complex but always contains an element of probabilistic infilling.

Generally, in biography, isolated facts lead us to types, and it is the relationship between facts that leads us to nuance these types, depart from them, or develop complex narratives. A major strength of osteobiography is its ability to incorporate multiple strands of evidence to support such narratives. Understanding that somebody is both male and upper class tells us far more than each fact does on its own; if you add the fact that he lived to old age, or moved geographically during his lifetime, or plied a specialized trade, it prompts us to develop relations between these facts, to construct a life narrative. This process may be a form of intersectionality, of seeing somebody's life as structured not by a single dimension but by a conjunction of many dimensions and circumstances. It is obvious that the broader the range of potential information, the more complex or nuanced a portrait may emerge. The textual record tends to give us information on a narrow range of wavelengths, and it is hard to expand beyond what is present on the page. The skeletal record affords a much wider range of potential information, and it is easier to associate different kinds of information. Moreover, while (for many areas of history) the textual record tends to be static and closed, the range of information available from skeletal sources is constantly expanding as new methods are developed. For most people in most times, osteobiography affords the basis for more complex and nuanced lives.

Osteobiography's second advantage concerns experience and self-understanding. Osteobiography is not the administrative history of someone being taxed, conscripted, or legally cited by an external authority; it is the history of the body and its experience. Humans understand themselves through their bodies. One dimension is self-image, for example via stature and facial appearance. Another is health status, one's understanding of one's own body as well or ill, and as well or ill in particular ways (e.g., as subject to common or universal maladies, or as afflicted by unusual or inexplicable conditions). Age is also salient. In most premodern societies, what counts is the social age of the body, not chronometric age (cf. Sofaer 2011). Whether or not most ordinary medieval people had a precise notion of their own age in years, age was typically measured in terms of physical characteristics and capability (Gilchrist 2012). Age was understood through collectively remembered historical landmarks, social stages such as marriage, and the evidence of people's own bodies: menstruation, fertility, strength, gray hair, aching joints, and lost teeth en route to finishing up (in Shakespeare's words [As You Like It, act II, scene 7], building upon the medieval trope of the "ages of man") "sans teeth, sans eyes, sans taste, sans everything." Writing a person's history through his or her body, rather than through random textual citations, thus gets us much closer to that person's self-understanding; it is history from the inside.

Finally, osteobiography allows a more democratic history. Almost without exception, the textual record is systematically biased toward the more affluent. Moreover, it is overwhelmingly male, leaving women less historically visible. It holds other biases too, such as often excluding children, marginalized people, and excluded minorities. The "people without history" (Wolf 1982) thus include not only colonized peoples but different or subaltern people of all kinds. The skeletal record certainly is not without bias, starting first and foremost with the question of who is buried within or excluded from a particular site, and moving on to differential visibility of sites, preservation, and excavation. But, by and large, the criteria for osteobiography are less biased and more likely to give a true cross section of human experience; we are far more likely to encounter a woman, a child, or a poor person in the grave than on the page. F958 is an ordinary person; such people, who made up the overwhelming mass of medieval people, offer very little material for the textual biographer to examine, when they can be seen at all. Osteobiography affords history for those below the textual threshold. For Everyman, and above all for Everywoman, whether rural peasants or the urban poor, osteobiography offers allows us to see women, children, and marginalized or excluded people. This makes osteobiography especially valuable for feminist, Marxist, and "people's history" (Zinn 1980). It is 
our best chance for understanding the lives of the vast bulk of humanity in the vast majority of the past.

\section{Acknowledgments}

We are grateful to many colleagues who have helped in this research. Natasha Dodwell (Cambridge Archaeological Unit, now of Oxford Archaeology East) conducted the preliminary assessment of the St. John's collection. Craig Alexander contributed to the Bayesian calibration of radiocarbon dates. Chris Rynn (University of Dundee Centre for Anatomy and Human Identification) created a facial reconstruction of 958 (Fig. 9). Mark Gridley, archaeological illustrator par excellence, created Figure 10. We thank St. John's College, Cambridge, for access to college archives and for permission to publish Figure 3. We are grateful to St. John's College, the McDonald Institute for Archaeological Research, and the Wellcome Foundation (Collaborative Grant 200368/Z/15/Z "After the Plague: Health and History in Medieval Cambridge") for financial support, and to the McDonald Institute and the Cambridge Archaeological Unit for support of many kinds. Finally, we are grateful to three anonymous reviewers whose comments helped to improve the manuscript.

\section{References Cited}

Arts, Nico. 2003. Marcus of Eindhoven: An Archaeological Biography of a Medieval Child. Matrijs, Utrecht.

Baker, Brenda J., Claire E. Terhune, and Amy Papalexandrou. 2012. Sew long? The osteobiography of a woman from medieval Polis, Cyprus. In The Bioarchaeology of Individuals, edited by Ann L. W. Stodder and Ann M. Palkovich. University Press of Florida, Gainesville, pp. 151-161.

Bates, David, Julia Crick, and Sarah Hamilton. 2006. Writing Medieval Lives: Essays in Honour of Frank Barlow. Boydell \& Brewer, Woodbridge.

Bennett, Henry S. 1955. Six Medieval Men and Women. Cambridge University Press, Cambridge.

Brooks, Sheilagh Thompson, and Judy Myers Suchey. 1990. Age determination based on the os pubis: A comparison of the Acsadi-Nemeskeri and Suchey-Brooks methods. Human Evolution 5(3):227-238. DOI: 10.1007/BF02437238.

Brothwell Donald. 1981. Digging up Bones: The Excavation, Treatment and Study of Human Skeletal Remains. Cornell University Press, Ithaca, NY.

Bryan, Peter. 1999. Cambridge: The Shaping of the City. Privately published, Cambridge

Buckberry, Jo, and Andrew Chamberlain. 2002. Age estimation from the auricular surface of the ilium: A revised method. American Journal of Physical Anthropology 119(3):231-239. DOI: 10.1002/ajpa.10130.

Buckley, Richard, Mathew Morris, Jo Appleby, Turi King, Deirdre O'Sullivan, and Lin Foxhall. 2013. 'The king in the car park': New light on the death and burial of Richard III in the
Grey Friars Church, Leicester, in 1485. Antiquity 87(336):51938. DOI: 10.1017/S0003598X00049103.

Buikstra, Jane E., and Douglas H. Ubelaker. (1994). Standards for Data Collection from Human Remains.: Arkansas Archeological Survey Research Series No. 44. Arkansas Archeological Survey, Fayetteville.

Cam, H. M. 1959. The city of Cambridge. In A History of the County of Cambridge and the Isle of Ely, Volume III, edited by J. P. C. Roach. Oxford University Press, Oxford, pp. 1-149.

Cessford, Craig. 2012. The Old Divinity School, Cambridge: An Archaeological Excavation. Cambridge Archaeological Unit Report No. 1094. DOI: 10.5284/1028592.

Cessford, Craig. 2015. The St. John's Hospital Cemetery and environs, Cambridge: Contextualizing the medieval dead. Archaeological Journal 172:52-120. DOI: 10.1080/00665983.2014 .984960 .

Cessford, Craig. 2017. Former Old Examination Hall, North Range Buildings, New Museums Site, Cambridge: An Archaeological Excavation. Cambridge Archaeological Unit Report 1377.

Craddock, Pam T., and Vince L. Gregory. n.d. Excavation of the Graveyard of All Saints-AD-Castra, Cambridge. Unpublished typescript.

Crouch, David. 1997. The culture of death in the Anglo-Norman world. In Anglo-Norman Political Culture and the 12th-Century Renaissance, edited by C. Warren Hollister. Boydell \& Brewer, Woodbridge, pp. 157-80.

Davis, Natalie Z. 1984. The Return of Martin Guerre. Harvard University Press, Cambridge.

Faber, Thomas E. 2006. An Intimate History of the Parish of St. Clement in Cambridge, 1250-1950. T.E. Faber Estate, Cambridge.

Faccia, Kathleen, and Williams Robert. 2008. Schmorl's nodes: Clinical significance and implications for the bioarchaeological record. International Journal of Osteoarchaeology 18(1):2844. DOI 10.1002/oa.924.

Fleming, Robin. 2006. Bones for historians: Putting the body back into biography. In Writing Medieval Biography, 750-1250: Essays in Honour of Frank Barlow, edited by David Bates, Julia Crick, and Sarah Hamilton. Boydell \& Brewer, Woodbridge, pp. 29-48.

Fleming, Robin. 2009. Writing biography at the edge of history. American Historical Review 114(3):606-614. DOI: 10.1086/ahr .114.3.606.

Gilchrist, Roberta. 2012. Medieval Life: Archaeology and the Life Course. Boydell \& Brewer, Woodbridge.

Gilchrist, Roberta, and Barney Sloane. 2005. Requiem: The Medieval Monastic Cemetery in Britain. MOLAS, London.

Ginzburg, Carlo. 1992. The Cheese and the Words: The Cosmos of a Sixteenth Century Miller. Johns Hopkins University Press, Baltimore.

Grauer, Anne L., and Andrew G. Miller. 2017. Flesh on the bones: A historical and bioarchaeological exploration of violence, trauma, sex and gender in medieval England. Fragments: Interdisciplinary Approaches to the Study of Ancient and Medieval Pasts 6:38-79.

Hamre, Stian Suppersberger., Geir Atle Ersland, Valérie Daux, Walther Parson, and Caroline Wilkinson. 2017. Three individuals, three stories, three burials from medieval Trondheim, Norway. PLoS ONE 12(7):e0180277. DOI: 10.1371/journal.pone .0180277 .

Inskip, Sarah, Christiana L. Scheib, Anthony Wilder Wohns, Xiangyu Ge, Toomas Kivisild, and John Robb. 2018. Evaluating macroscopic sex estimation methods using genetically sexed archaeological material: The medieval skeletal collection from St John's Divinity School, Cambridge. American Journal of Physical Anthropology 168(2):340-351. DOI: 10.1002/ajpa.23753. 
Knüsel, Christopher J., Catherine M. Batt, Gordon Cook, Janet Montgomery,Gundula Müldner, Alan R. Ogden, Carol Palmer, Ben Stern, John Todd, and Andrew S. Wilson. 2010. The identity of the St Bees Lady, Cumbria: An osteobiographical approach. Medieval Archaeology 54(1):271-311. DOI: 10.1179/1745 81710X12790370815931.

Le Roy Ladurie, Emanuel. 1978. Montaillou: The Promised Land of Error. Scolar Press, London.

Lobel, Mary D., ed. 1975. Historic Towns: The Atlas of Historic Towns (Volume 2: Bristol, Cambridge, Coventry, Norwich). Scolar Press, for the Historic Towns Trust, London.

Maitland, Frederic W. 1898. Township and Borough. Cambridge University Press, Cambridge.

Matczak, Magdalana D., and Tomasz Kozłowski. 2017. Dealing with difference: Using the osteobiographies of a woman with leprosy and a woman with gigantism from medieval Poland to identify practices of care. In New Developments in the Bioarchaeology of Care: Bioarchaeology and Social Theory, edited by Lorna Tilley and Alecia Schrenk. Springer, Cham, pp. 125-151. Power, Eileen. 1924. Medieval People. Methuen, London.

Prescott, Elizabeth. 1992. The English Medieval Hospital, C1050-1640. Cromwell Press, Melkham.

Price, Mary. 2013. How Did the Social Changes of the Fourteenth Century Affect the Everyday Lives of English People? A Case Study from St. John's Divinity School, Cambridge. Unpublished undergraduate dissertation, University of Cambridge.

Rawcliffe, Carole. 1995. The Hospitals of Medieval Norwich. Centre of East Anglian Studies, Norwich.

Reaney, P. H., and R. M. Wilson. 1991. A Dictionary of English Surnames. Rev. 3rd ed. Routledge, London.
Robb, John. 2009. Towards a critical Ötziography: Writing prehistoric bodies. In Social Bodies, edited by Helen Lambert and Maryon McDonald. Berghahn, Oxford, pp., 100-128.

Rousseuw, Peter J., Ida Ruts, and John W. Tukey. 1999. The bagplot: A bivariate boxplot. American Statistician 53(4):382-387. DOI: $10.2307 / 2686061$.

Rubin, Miriam. 1987. Charity and Community in Medieval Cambridge. Cambridge University Press, Cambridge.

Sofaer, Joanna. 2011. Towards a social bioarchaeology of age. In Social Bioarchaeology, edited by Sabrina C. Agarwal and Bonnie A. Glencross. Blackwell, Oxford, pp. 285-311.

Taylor, Allison. 1999. Cambridge: The Hidden History. Tempus, Stroud.

Tringham, Ruth. 1991. Households with faces: The challenge of gender in prehistoric archaeological remains. In Engendering Archaeology, edited by Joan Gero and Margaret Conkey. Blackwell, Oxford, pp. 93-131.

Trotter, Mildred, and Goldine Gleser. 1958. A re-evaluation of estimation of stature taken during life and of long bones after death. American Journal of Physical Anthropology 16(1):79-123. DOI: 10.1002/ajpa.1330160106.

Underwood, Malcolm G. 2008. The Cartulary of the Hospital of St. John the Evangelist, Cambridge. Cambridgeshire Records Society, Cambridge.

Wilkinson, Caroline. 2004. Forensic Facial Reconstruction. Cambridge University Press, Cambridge.

Wolf, Eric. 1982. Europe and the People without History. University of California Press, Berkeley.

Zinn, Howard. 1980. A People's History of the United States. HarperCollins, New York. 